\title{
Predictive Values of Semi-Quantitative Procalcitonin Test and Common Biomarkers for the Clinical Outcomes of Community-Acquired Pneumonia
}

\author{
Motoi Ugajin MD, Kenichi Yamaki MD PhD, Natsuko Hirasawa MD, \\ and Takeo Yagi MD PhD
}

\begin{abstract}
BACKGROUND: The semi-quantitative serum procalcitonin test (Brahms PCT-Q) is available conveniently in clinical practice. However, there are few data on the relationship between results for this semi-quantitative procalcitonin test and clinical outcomes of community-acquired pneumonia (CAP). We investigated the usefulness of this procalcitonin test for predicting the clinical outcomes of CAP in comparison with severity scoring systems and the blood urea nitrogen/serum albumin (B/A) ratio, which has been reported to be a simple but reliable prognostic indicator in our prior CAP study. METHODS: This retrospective study included data from subjects who were hospitalized for CAP from August 2010 through October 2012 and who were administered the semiquantitative serum procalcitonin test on admission. The demographic characteristics; laboratory biomarkers; microbiological test results; Pneumonia Severity Index scores; confusion, urea nitrogen, breathing frequency, blood pressure, $\geq 65$ years of age (CURB-65) scale scores; and age, dehydration, respiratory failure, orientation disturbance, pressure (A-DROP) scale scores on hospital admission were retrieved from their medical charts. The outcomes were mortality within 28 days of hospital admission and the need for intensive care. RESULTS: Of the 213 subjects with CAP who were enrolled in the study, 20 died within 28 days of hospital admission, and 32 required intensive care. Mortality did not differ significantly among subjects with different semi-quantitative serum procalcitonin levels; however, subjects with serum procalcitonin levels $\geq 10.0 \mathrm{ng} / \mathrm{mL}$ were more likely to require intensive care than those with lower levels $(P<.001)$. The elevation of semi-quantitative serum procalcitonin levels was more frequently observed in subjects with proven etiology, especially pneumococcal pneumonia. Using the receiver operating characteristic curves for mortality, the area under the curve was 0.86 for Pneumonia Severity Index class, 0.81 for B/A ratio, 0.81 for A-DROP, 0.80 for CURB-65, and 0.57 for semi-quantitative procalcitonin test. CONCLUSIONS: The semi-quantitative serum procalcitonin level on hospital admission was less predictive of mortality from CAP compared with the B/A ratio. However, the subjects with serum procalcitonin levels $\geq 10.0 \mathrm{ng} / \mathrm{mL}$ were more likely to require intensive care than those with lower levels. Key words: community-acquired pneumonia; semi-quantitative procalcitonin test; blood urea nitrogen; albumin; mortality; severity. [Respir Care 2014;59(4):564-573. (C) 2014 Daedalus Enterprises]
\end{abstract}

Introduction

Community-acquired pneumonia (CAP) is a serious illness and a common cause of death. Clinicians often wish

The authors are affiliated with the Department of Respiratory Medicine, Ichinomiya-Nishi Hospital, Ichinomiya City, Aichi Prefecture, Japan. Supplementary material related to this paper is available at http:// www.rcjournal.com

The authors have disclosed no conflicts of interest. to evaluate the disease severity and risk for mortality in patients with CAP. Therefore, many severity scoring systems for CAP have been introduced throughout the world.

Correspondence: Motoi Ugajin MD, Department of Respiratory Medicine, Ichinomiya-Nishi Hospital, 1 Hira, Kaimei, Ichinomiya City 4940001, Japan. E-mail: ugarin2001@ @ahoo.co.jp.

DOI: $10.4187 /$ respcare. 02807 
Of these scoring systems, the Pneumonia Severity Index is recommended by the American Thoracic Society and the Infectious Disease Society of America ${ }^{1}$; the confusion, urea nitrogen, breathing frequency, blood pressure, $\geq 65$ years of age (CURB-65) scale is recommended by the British Thoracic Society ${ }^{2}$; and the age, dehydration, respiratory failure, orientation disturbance, pressure (ADROP) scale is recommended by the Japanese Respiratory Society. ${ }^{3}$ However, these scoring systems are subjective. It is often difficult to evaluate the mental status of CAP patients who are elderly or have dementia, and the severity score assigned may therefore vary among clinicians. ${ }^{4,5}$

The quantitative serum procalcitonin level has been reported to be a useful predictive prognostic marker in CAP. ${ }^{6-8}$ However, to measure quantitative procalcitonin levels, $\sim 16$ million yen are necessary as a capital investment before the test can be conducted in Japan. Therefore, the medical facilities with the capability to measure quantitative procalcitonin levels immediately after blood sampling are limited due to the cost of the analysis. In clinical practice, a semi-quantitative serum procalcitonin test kit (PCT-Q, Brahms GmbH, Hennigsdorf, Germany) is available conveniently and costs only 2,800 yen for each measurement without the need for capital investment. This kit measures serum procalcitonin levels using an immunochromatographic assay with an incubation period of $\sim 30 \mathrm{~min}$, and it categorizes the serum procalcitonin levels as 1 of 4 grades $(<0.5,0.5$ to $<2.0,2.0$ to $<10.0$, or $\geq 10.0$ $\mathrm{ng} / \mathrm{mL}$ ). However, there are few data on the usefulness of the semi-quantitative serum procalcitonin test for predicting clinical outcomes of patients with CAP. To our knowledge, only one report, by Kasamatsu et al, ${ }^{9}$ showed that the semi-quantitative procalcitonin test was useful for predicting mortality from CAP, but it was not as useful as the Pneumonia Severity Index, CURB-65 scale, and A-DROP scale. In short, the significance of performing this semiquantitative serum procalcitonin test on patients with CAP has not yet been adequately revealed.

Several earlier studies showed that, of the commonly used laboratory biomarkers, higher blood urea nitrogen levels and lower serum albumin levels indicate poor clinical outcomes for patients with CAP..$^{2,10-13}$ Moreover, our prior prospective observational study showed that the blood urea nitrogen/serum albumin (B/A) ratio was more accurate for predicting mortality from and severity of CAP than were blood urea nitrogen or serum albumin levels alone. ${ }^{14}$

In this single-center retrospective study, we investigated the predictive ability of the semi-quantitative serum procalcitonin test for clinical outcomes of CAP in comparison with severity scoring systems and commonly used laboratory biomarkers.

\section{QUICK LOOK}

\section{Current knowledge}

Community-acquired pneumonia (CAP) is a serious illness and a common cause of death. Serum procalcitonin levels have been reported to be a useful predictive prognostic marker in sepsis and CAP.

\section{What this paper contributes to our knowledge}

The semi-quantitative serum procalcitonin level on admission was less predictive of mortality from CAP compared with the blood urea nitrogen/serum albumin ratio. Subjects with serum procalcitonin levels $\geq 10.0 \mathrm{ng} / \mathrm{mL}$ were more likely to require intensive care.

\section{Methods}

\section{Ethics}

The informed consent obtained from all subjects was verbal because this study protocol included no interventional procedures and used only a database that had guaranteed confidentiality. This study protocol and consent procedure followed the guidelines of the Declaration of Helsinki and were approved by the Research Ethics Review Committee of Ichinomiya-Nishi Hospital (No. 20135).

\section{Study Population}

Patients with CAP who were admitted to IchinomiyaNishi Hospital (a 400-bed teaching hospital; Ichinomiya City, Aichi Prefecture, Japan) from August 2010 through October 2012 and who were administered the semi-quantitative serum procalcitonin test on hospital admission were enrolled in this study. CAP was diagnosed in patients $\geq 18 \mathrm{y}$ old who were admitted to the hospital from the community, including a nursing home; were not exposed to antibiotics during the $14 \mathrm{~d}$ before study enrollment; had not been hospitalized in the $90 \mathrm{~d}$ before study enrollment; presented with a new radiographic infiltrate; and exhibited at least 2 compatible clinical symptoms (eg, body temperature $>38^{\circ} \mathrm{C}$, productive cough, chest pain, shortness of breath, and crackles on auscultation). Patients were excluded from the study if they were chronically immunosuppressed (ie, were undergoing chemotherapy or other therapy with corticosteroids or other immunosuppressive agents or were infected with human immunodeficiency virus), had advanced liver disease, or had received hemodialysis or been found to have a serum creatinine level $\geq 1.5 \mathrm{mg} / \mathrm{dL}$ due to chronic kidney disease. 


\section{Semi-Quantitative Procalcitonin in Community-Acquired Pneumonia}

\section{Study Design}

The following variables were retrieved from medical charts: (1) demographic characteristics (age and sex); (2) coexisting illnesses; (3) clinical data at the time of hospital admission (body temperature, respiratory rate, percutaneous oxygen saturation, blood pressure, cardiac frequency, and mental status); (4) laboratory and radiographic findings on hospital admission; (5) Pneumonia Severity Index, CURB-65 scale, and A-DROP scale scores on hospital admission; (6) causative pathogens; (7) intravenous initial antibiotic regimens; and (8) clinical outcomes.

The clinical outcomes were mortality within $28 \mathrm{~d}$ of hospital admission and the requirement for intensive care, defined as the necessity of using mechanical ventilation or vasopressor therapy against shock. The A-DROP scale is a 5-point scoring system similar to the CURB-65 scale, and it includes confusion, blood urea nitrogen level $>20 \mathrm{mg} / \mathrm{dL}$, percutaneous oxygen desaturation $<90 \%$, systolic blood pressure $<90 \mathrm{~mm} \mathrm{Hg}$, and age $\geq 70$ y for men or $\geq 75$ y for women. ${ }^{3}$ Causative pathogens were diagnosed as the following criteria: (1) for Streptococcus pneumoniae, $3+$ growth of sputum culture or the presence of antigen in urine (2); for Legionella pneumophila, the presence of antigen in urine; and (3) for other bacteria, $3+$ growth of sputum culture.

The end point of this study was to evaluate the predictive ability of severity scoring systems and laboratory biomarkers for the clinical outcomes of patients with CAP, according to the Standards for Reporting of Diagnostic Accuracy Studies. ${ }^{15}$

\section{Procedures}

Procalcitonin was measured using an immunochromatographic semi-quantitative procalcitonin test kit (PCT-Q) that categorizes the serum procalcitonin levels as 1 of 4 grades $(<0.5,0.5$ to $<2.0,2.0$ to $<10.0$, or $\geq 10.0$ $\mathrm{ng} / \mathrm{mL}$ ). Blood urea nitrogen was measured using the enzymatic method with urease and glutamate dehydrogenase (Shino-Test Corporation, Tokyo, Japan). Serum C-reactive protein level was measured using the latex nephelometric assay (Nittobo Medical, Tokyo, Japan). Serum albumin level was measured using the bromocresol green method (Shino-Test Corporation) from August 2010 through December 2011 and the bromocresol purple method (Kainos Laboratories, Tokyo, Japan) from January through October 2012. The normal range of the serum albumin level is the same for both methods. Other biochemical markers were assayed using standard methods. Routine sampling to detect the causative pathogens included sputum and

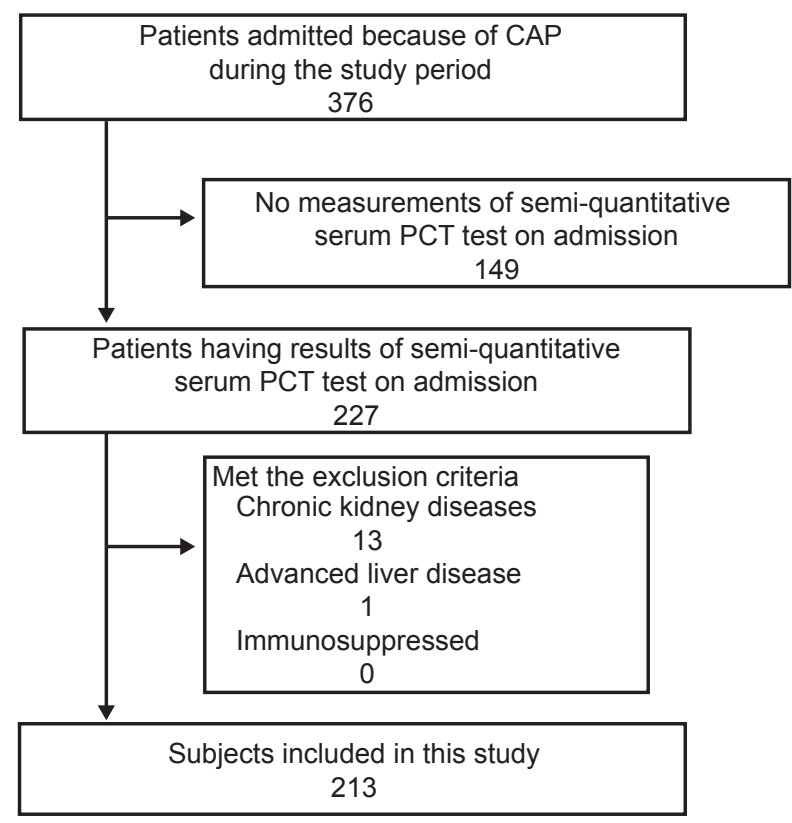

Fig. 1. Study flow chart. $\mathrm{PCT}=$ procalcitonin, $\mathrm{CAP}=$ communityacquired pneumonia.

urinary antigen tests for S. pneumoniae (Binax, Portland, Maine) and L. pneumophila serogroup 1 (Binax).

\section{Statistical Analysis}

Data are expressed as numbers or the median (25th to 75th percentile range). Differences between 2 groups were tested using the non-parametric Mann-Whitney $U$ test for continuous variables and the Fisher exact test for categorical variables. Receiver operating characteristic (ROC) curve analysis and calculation of the area under the curve were performed to assess the diagnostic ability of each potential indicator and to identify the optimal cutoff values for predicting mortality and the requirement for intensive care. A two-tailed $P$ value of $<.05$ was considered significant.

\section{Results}

\section{Clinical Characteristics}

A total of 376 patients with CAP were admitted to our hospital during the study period. Of these patients, 163 were excluded because no semi-quantitative procalcitonin measurement was performed on hospital admission $(n=149)$ or because of chronic kidney disease $(n=13)$ or advanced liver disease $(n=1)$. The remaining 213 subjects were enrolled in this study (Fig. 1). Their demographic characteristics are shown in Table 1. Fifty-nine subjects $(27.7 \%)$ were admitted to the hospital from a 
Table 1. Baseline Characteristics of Enrolled Subjects

\begin{tabular}{|c|c|}
\hline Characteristics & Values \\
\hline Total & 213 \\
\hline Age, y & $82(74-88)$ \\
\hline Male patients & $127(59.6)$ \\
\hline From nursing home & $59(27.7)$ \\
\hline Identification of pathogen & $99(46.5)$ \\
\hline Death within $28 \mathrm{~d}$ & $20(9.4)$ \\
\hline Intensive care requirement & $32(15.0)$ \\
\hline \multicolumn{2}{|l|}{ Coexisting illnesses } \\
\hline Chronic lung disease & $30(14.1)$ \\
\hline Diabetes mellitus & $32(15.0)$ \\
\hline Heart failure & $39(18.3)$ \\
\hline Neoplastic disease & $4(1.9)$ \\
\hline \multicolumn{2}{|l|}{ Intravenous initial antibiotics } \\
\hline Antipseudomonal $\beta$-lactams & $156(73.2)$ \\
\hline Tetracyclines & $62(29.1)$ \\
\hline Fluoroquinolones & $18(8.5)$ \\
\hline Clindamycin & $16(7.5)$ \\
\hline Macrolides & $3(1.4)$ \\
\hline Antibiotic combination therapy & $84(39.4)$ \\
\hline \multicolumn{2}{|l|}{ Pneumonia Severity Index class } \\
\hline $1-2$ & $24(11.3)$ \\
\hline 3 & $56(26.3)$ \\
\hline 4 & $87(40.8)$ \\
\hline 5 & $46(21.6)$ \\
\hline \multicolumn{2}{|l|}{ CURB-65 } \\
\hline $0-1$ & $66(31.0)$ \\
\hline 2 & $64(30.0)$ \\
\hline$\geq 3$ & $83(39.0)$ \\
\hline \multicolumn{2}{|l|}{ A-DROP } \\
\hline $0-1$ & $76(35.7)$ \\
\hline 2 & $55(25.8)$ \\
\hline$\geq 3$ & $82(38.5)$ \\
\hline \multicolumn{2}{|l|}{ Semi-quantitative procalcitonin } \\
\hline$<0.5 \mathrm{ng} / \mathrm{mL}$ & $103(48.4)$ \\
\hline 0.5 to $<2.0 \mathrm{ng} / \mathrm{mL}$ & $48(22.5)$ \\
\hline 2.0 to $<10.0 \mathrm{ng} / \mathrm{mL}$ & $33(15.5)$ \\
\hline$\geq 10.0 \mathrm{ng} / \mathrm{mL}$ & $29(13.6)$ \\
\hline Leukocyte count, $10^{9}$ cells $/ \mathrm{L}$ & $10.8(8.4-13.5)$ \\
\hline Hematocrit, \% & $36.7(33.4-39.7)$ \\
\hline C-reactive protein, $\mathrm{mg} / \mathrm{dL}$ & $15.1(7.0-21.2)$ \\
\hline Sodium, mEq/L & $139(136-141)$ \\
\hline Glucose, mg/dL & $125(106-152)$ \\
\hline Creatinine, $\mathrm{mg} / \mathrm{dL}$ & $0.78(0.64-1.06)$ \\
\hline Blood urea nitrogen, $\mathrm{mg} / \mathrm{dL}$ & $19.9(14.8-27.9)$ \\
\hline Albumin, g/dL & $3.4(3.0-3.8)$ \\
\hline $\mathrm{B} / \mathrm{A}$ ratio, $\mathrm{mg} / \mathrm{g}$ & $6.14(4.24-8.92)$ \\
\hline
\end{tabular}

nursing home. Twenty subjects $(9.4 \%)$ died within $28 \mathrm{~d}$ of hospital admission, and 32 subjects (15.0\%) required intensive care. Elevation of the semi-quantitative serum
Table 2. Causative Pathogens

\begin{tabular}{lccr}
\hline \hline \multicolumn{1}{c}{ Micro-organism } & Values & $\begin{array}{c}\text { Procalcitonin } \\
\geq 0.5 \mathrm{ng} / \mathrm{mL}\end{array}$ & $\begin{array}{c}P \\
\text { value* }\end{array}$ \\
\hline Identification of pathogen & $99(46.5)$ & 59 & .039 \\
S. pneumoniae & $43(20.2)$ & 29 & .013 \\
Klebsiella pneumonia & $13(6.1)$ & 7 & .569 \\
Pseudomonas aeruginosa & $11(5.2)$ & 5 & $>.999$ \\
Staphylococcus species & $8(3.8)$ & 6 & .144 \\
Haemophilus influenzae & $7(3.3)$ & 3 & $>.999$ \\
MRSA & $6(2.8)$ & 5 & .096 \\
Escherichia coli & $4(1.9)$ & 2 & $>.999$ \\
Moraxella catarrhalis & $2(0.9)$ & 0 & .503 \\
L pneumophila & $1(0.5)$ & 1 & .452 \\
Enterobacter species & $1(0.5)$ & 1 & .452 \\
Acinetobacter baumannii & $1(0.5)$ & 0 & $>.999$ \\
Proteus mirabilis & $1(0.5)$ & 0 & $>.999$ \\
Stenotrophomonas maltophilia & $1(0.5)$ & 0 & $>.999$ \\
Unknown & $114(53.5)$ & 51 & Reference \\
& & & \\
\hline Data are expressed as $n$ n(\%). & & & \\
* Comparison with patients whose causative pathogen was unknown. & \\
MRSA= methicillin-resistant Staphylococcus aureus & & \\
\hline
\end{tabular}

procalcitonin level $(\geq 0.5 \mathrm{ng} / \mathrm{mL})$ was observed in 110 subjects $(51.6 \%)$.

\section{Semi-Quantitative Serum Procalcitonin Levels and Causative Pathogens}

Causative pathogens were detected in 99 subjects (46.5\%) and are listed in Table 2. The most frequently detected pathogen was S. pneumoniae $(n=43,20.2 \%)$. Elevation of semi-quantitative serum procalcitonin levels ( $\geq 0.5 \mathrm{ng} / \mathrm{mL}$ ) was more frequently observed in subjects whose causative pathogen was detected than in those without proven etiology $(59.6 \%$ vs $44.7 \%, P=.039)$. In particular, significantly more subjects with pneumococcal etiology had an elevation of semi-quantitative serum procalcitonin levels $(67.4 \%, P=.013)$.

\section{Predictive Value for Mortality}

Table 3 shows a comparison of the demographic and clinical characteristics between the deceased and surviving subjects. The deceased subjects were more likely to be of advanced age, to have been nursing home inhabitants, to have required intensive care, and to have been treated with antipseudomonal $\beta$-lactam agents for the initial antibiotic therapy. Concerning severity scoring systems, the deceased subjects were more likely to have high Pneumonia Severity Index risk class, high CURB-65 scores, and high ADROP scores. Comparison of the commonly used laboratory biomarkers between the groups showed that the deceased subjects had higher blood urea nitrogen levels, 
Semi-Quantitative Procalcitonin in Community-Acquired Pneumonia

Table 3. Comparison of the Characteristics Between Deceased and Surviving Subjects With CAP

\begin{tabular}{|c|c|c|c|}
\hline Characteristics & $\begin{array}{c}\text { Deceased } \\
(n=20)\end{array}$ & $\begin{array}{l}\text { Surviving } \\
(n=193)\end{array}$ & $P$ value \\
\hline Age, y & $87(83-89)$ & $81(73-87)$ & .004 \\
\hline Male patients & $10(50.0)$ & $117(60.6)$ & .47 \\
\hline From nursing home & $12(60.0)$ & $47(24.4)$ & $<.001$ \\
\hline Identification of pathogens & $13(65.0)$ & $86(44.6)$ & .1 \\
\hline Intensive care requirement & $14(70.0)$ & $18(9.3)$ & $<.001$ \\
\hline Coexisting illness & $10(50.0)$ & $81(42.0)$ & .49 \\
\hline \multicolumn{4}{|l|}{ Intravenous initial antibiotics } \\
\hline Antipseudomonal $\beta$-lactams & $19(95.0)$ & $137(71.0)$ & .02 \\
\hline Tetracyclines & $6(30.0)$ & $56(29.0)$ & $>.999$ \\
\hline Fluoroquinolones & $2(10.0)$ & $16(8.3)$ & .68 \\
\hline Clindamycin & $1(5.0)$ & $15(7.8)$ & $>0.999$ \\
\hline Macrolides & 0 & $3(1.6)$ & $>.999$ \\
\hline Antibiotic combination therapy & $8(40.0)$ & $76(39.4)$ & $>.999$ \\
\hline Pneumonia Severity Index class & $5(5-5)$ & $4(3-4)$ & $<.001$ \\
\hline CURB-65 & $3(3-4)$ & $2(1-3)$ & $<.001$ \\
\hline A-DROP & $3(3-4)$ & $2(1-3)$ & $<.001$ \\
\hline \multicolumn{4}{|l|}{ Semi-quantitative procalcitonin } \\
\hline$<0.5 \mathrm{ng} / \mathrm{mL}$ & $8(40.0)$ & $95(49.2)$ & \\
\hline 0.5 to $<2.0 \mathrm{ng} / \mathrm{mL}$ & $4(20.0)$ & $44(22.8)$ & $>0.999 *$ \\
\hline 2.0 to $<10.0 \mathrm{ng} / \mathrm{mL}$ & $3(15.0)$ & $30(15.5)$ & $.73 *$ \\
\hline$\geq 10.0 \mathrm{ng} / \mathrm{mL}$ & $5(25.0)$ & $24(12.4)$ & $.16^{*}$ \\
\hline Leukocyte count, $10^{9}$ cells $/ \mathrm{L}$ & $10.7(8.6-14.7)$ & $10.8(8.3-13.4)$ & .56 \\
\hline Hematocrit, \% & $35.6(29.5-38.9)$ & $37.2(33.7-39.9)$ & .17 \\
\hline C-reactive protein, $\mathrm{mg} / \mathrm{dL}$ & $15.22(8.3-23.7)$ & $15.06(6.8-20.5)$ & .58 \\
\hline Sodium, mEq/L & $141(134-148)$ & $139(136-141)$ & .23 \\
\hline Glucose, mg/dL & $116(101-153)$ & $126(107-152)$ & .38 \\
\hline Creatinine, mg/dL & $0.78(0.62-1.46)$ & $0.77(0.65-1.02)$ & .35 \\
\hline Blood urea nitrogen, $\mathrm{mg} / \mathrm{dL}$ & $33.8(18.5-51.3)$ & $19.5(14.7-26.6)$ & .001 \\
\hline Albumin, g/dL & $3.1(2.2-3.4)$ & $3.5(3.1-3.9)$ & .001 \\
\hline $\mathrm{B} / \mathrm{A}$ ratio, $\mathrm{mg} / \mathrm{g}$ & $12.00(8.1-18.3)$ & $5.74(4.14-8.6)$ & $<.001$ \\
\hline \multicolumn{4}{|c|}{$\begin{array}{l}\text { Data are expressed as } n(\%) \text { or median }(25 \text { th to } 75 \text { th percentile range). } \\
\text { * Comparison with semi-quantitative procalcitonin levels of }<0.5 \mathrm{ng} / \mathrm{mL} \text {. } \\
\text { CAP }=\text { community-acquired pneumonia } \\
\text { CURB- } 65=\text { confusion, urea nitrogen, breathing frequency, blood pressure, } \geq 65 \text { years of age } \\
\text { A-DROP }=\text { age, dehydration, respiratory failure, orientation disturbance, pressure } \\
\text { B/A ratio = blood urea nitrogen to serum albumin ratio }\end{array}$} \\
\hline
\end{tabular}

higher $\mathrm{B} / \mathrm{A}$ ratios, and lower serum albumin levels than surviving subjects. Mortality did not differ significantly according to the subjects' semi-quantitative serum procalcitonin levels (see Table 3 and Fig. 2A).

The ROC curves for predicting mortality within $28 \mathrm{~d}$ of hospital admission are shown in Figure 3A. The area under the curve values were 0.86 (95\% CI $0.78-0.94)$ for the Pneumonia Severity Index class, 0.81 (95\% CI 0.72-0.91) for the B/A ratio, 0.81 (95\% CI $0.74-0.89$ ) for the ADROP score, 0.80 (95\% CI 0.73-0.88) for the CURB-65 score, 0.74 (95\% CI $0.63-0.84$ ) for the serum albumin level, 0.73 (95\% CI 0.61-0.85) for the blood urea nitrogen level, 0.57 (95\% CI $0.44-0.71$ ) for the semi-quantitative serum procalcitonin test result, and 0.54 (95\% CI $0.40-$ $0.67)$ for the serum C-reactive protein level.

\section{Predictive Value for the Need for Intensive Care}

Table 4 shows a comparison of the demographic and clinical characteristics of subjects who did or did not receive intensive care. The subjects who required intensive care were more likely to be of advanced age, to have been nursing home inhabitants, and to have been treated with antipseudomonal $\beta$-lactam agents as the initial antibiotic therapy. Concerning severity scoring systems, the subjects who required intensive care were more likely to have high Pneumonia Severity Index risk class, high CURB-65 scores, and high A-DROP scores. Comparison of the commonly used laboratory biomarkers between the groups showed that subjects who required intensive care had higher blood urea nitrogen levels, higher B/A ratios, and lower serum 

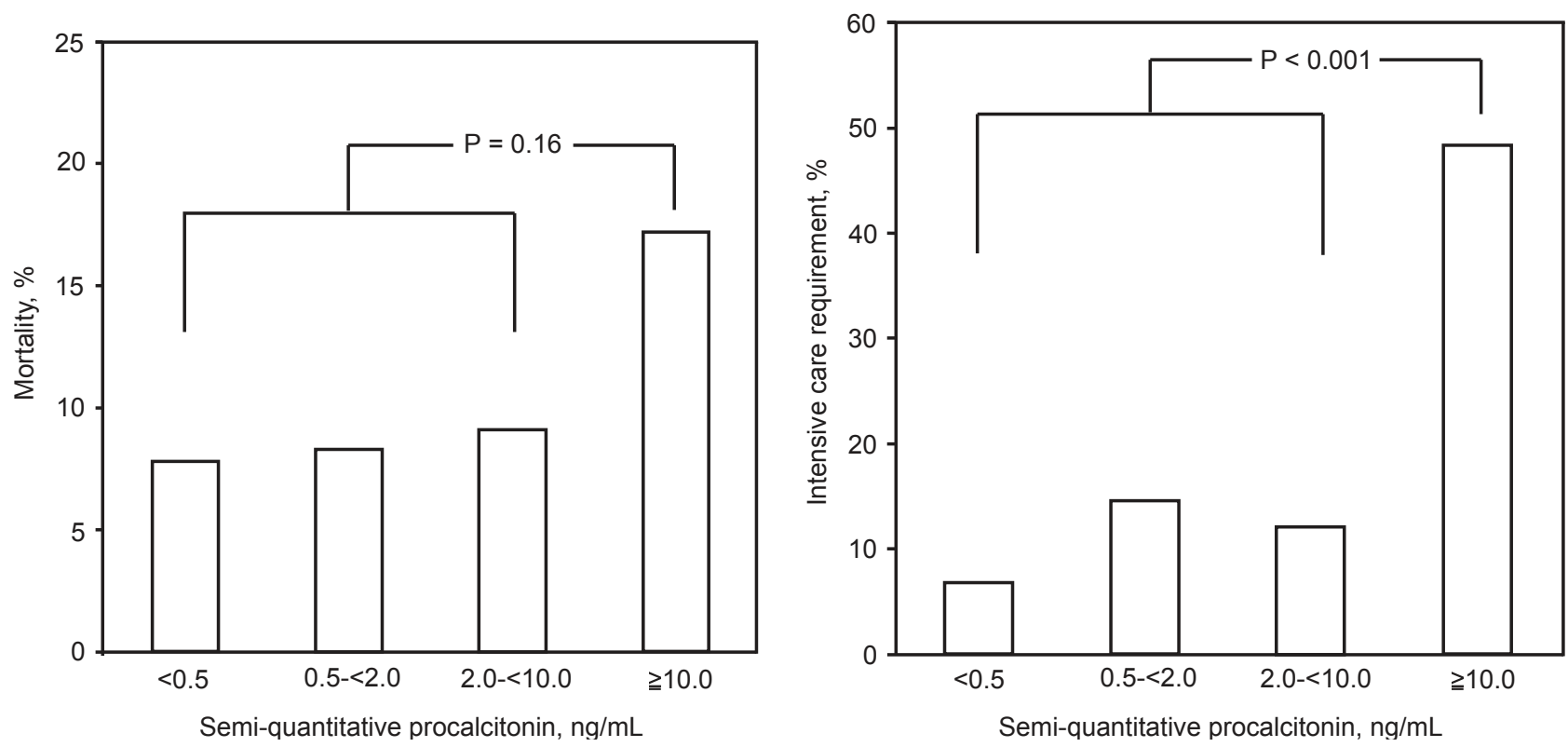

Fig. 2. Distribution of subjects with different semi-quantitative procalcitonin levels. Left - In relation to mortality. Right - In relation to intensive care requirements.
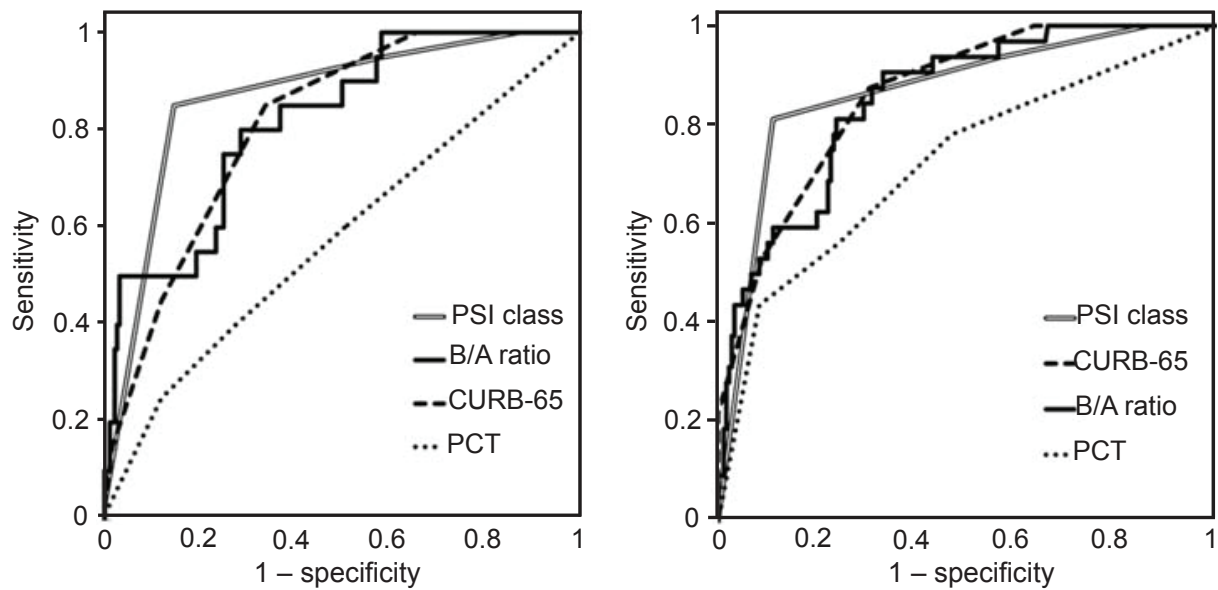

Fig. 3. Analysis of the ROC curves. Left: for predicting mortality. The area under the curve values were 0.86 for the Pneumonia Severity Index (PSI) class; 0.81 for the blood urea nitrogen/serum albumin (B/A) ratio; 0.80 for confusion, urea nitrogen, breathing frequency, blood pressure, $\geq 65$ years of age (CURB-65); and 0.57 for the semi-quantitative procalcitonin (PCT) test. Right: for predicting the need for intensive care. The area under the curve values were 0.87 for the Pneumonia Severity Index class, 0.86 for CURB- $65,0.85$ for the B/A ratio, and 0.72 for the semi-quantitative procalcitonin test.

albumin levels than those who did not require intensive care. Subjects with serum procalcitonin levels $\geq 10.0$ $\mathrm{ng} / \mathrm{mL}$ were significantly more likely to require intensive care than those with levels $<10.0 \mathrm{ng} / \mathrm{mL}(P<.001)$ (see Fig. 2B).

The ROC curves for predicting the need for intensive care are shown in Figure 3B. The area under the curve values were 0.87 (95\% CI 0.80-0.93) for the Pneumonia Severity Index class, 0.86 (95\% CI $0.81-0.92)$ for the A-DROP score, 0.86 (95\% CI 0.80-0.92) for the CURB-65 score, 0.85 (95\% CI $0.79-0.91)$ for the $\mathrm{B} / \mathrm{A}$ ratio, 0.82
(95\% CI 0.74-0.90) for the blood urea nitrogen level, 0.72 (95\% CI $0.62-0.82$ ) for the semi-quantitative serum procalcitonin test result, 0.67 (95\% CI $0.57-0.76)$ for the serum albumin level, and 0.56 (95\% CI $0.44-0.67)$ for the serum C-reactive protein level.

\section{Discussion}

In the present CAP study, we showed that (1) the semiquantitative serum procalcitonin test performed on hospital admission had little predictive value for mortality; (2) 
Semi-Quantitative Procalcitonin in Community-Acquired Pneumonia

Table 4. Comparison of the Characteristics Between Subjects With and Without Intensive Care

\begin{tabular}{|c|c|c|c|}
\hline Characteristics & $\begin{array}{l}\text { IC requirement } \\
\quad(n=32)\end{array}$ & $\begin{array}{c}\text { No IC requirement } \\
\quad(n=181)\end{array}$ & $P$ value \\
\hline Age, y & $85(82-90)$ & $80(72-87)$ & .001 \\
\hline Male patients & $20(62.5)$ & $107(59.1)$ & .846 \\
\hline From nursing home & $17(53.1)$ & $42(23.2)$ & .001 \\
\hline Identification of pathogens & $18(56.3)$ & $81(44.8)$ & .253 \\
\hline Coexisting illness & $17(53.1)$ & $74(40.9)$ & .245 \\
\hline \multicolumn{4}{|l|}{ Intravenous initial antibiotics } \\
\hline Antipseudomonal $\beta$-lactams & $30(93.8)$ & $126(69.6)$ & .004 \\
\hline Tetracyclines & $10(31.3)$ & $52(28.7)$ & .833 \\
\hline Fluoroquinolones & $5(15.6)$ & $13(7.2)$ & .158 \\
\hline Clindamycin & $3(9.4)$ & $13(7.2)$ & .714 \\
\hline Macrolides & 0 & $3(1.7)$ & $>.999$ \\
\hline Antibiotic combination therapy & $15(46.9)$ & $69(38.1)$ & .433 \\
\hline Pneumonia Severity Index class & $5(5-5)$ & $4(3-4)$ & $<.001$ \\
\hline CURB-65 & $4(3-4)$ & $2(1-3)$ & $<.001$ \\
\hline A-DROP & $4(3-4)$ & $2(1-3)$ & $<.001$ \\
\hline \multicolumn{4}{|l|}{ Semi-quantitative procalcitonin } \\
\hline$<0.5 \mathrm{ng} / \mathrm{mL}$ & 7 (21.9) & $96(53.0)$ & \\
\hline 0.5 to $<2.0 \mathrm{ng} / \mathrm{mL}$ & 7 (21.9) & $41(22.7)$ & $.14 *$ \\
\hline 2.0 to $<10.0 \mathrm{ng} / \mathrm{mL}$ & $4(12.5)$ & $29(16.0)$ & $.461^{*}$ \\
\hline$\geq 10.0 \mathrm{ng} / \mathrm{mL}$ & $14(43.8)$ & $15(8.3)$ & $<.001^{*}$ \\
\hline Leukocyte count, $10^{9}$ cells $/ \mathrm{L}$ & $11.0(7.7-13.3)$ & $10.8(8.4-13.6)$ & .89 \\
\hline Hematocrit, \% & $35.4(31.6-38.8)$ & $37.2(33.9-39.9)$ & .15 \\
\hline C-reactive protein, $\mathrm{mg} / \mathrm{dL}$ & $15.7(7.1-25.9)$ & $15.1(7.04-20.4)$ & .312 \\
\hline Sodium, mEq/L & $140(135-145)$ & $139(136-141)$ & .161 \\
\hline Glucose, mg/dL & $122(101-155)$ & $125(107-152)$ & .686 \\
\hline Creatinine, $\mathrm{mg} / \mathrm{dL}$ & $1.06(0.66-1.15)$ & $0.76(0.62-0.98)$ & .056 \\
\hline Blood urea nitrogen, $\mathrm{mg} / \mathrm{dL}$ & $33.1(26.3-50.0)$ & $18.6(14.4-25.4)$ & $<.001$ \\
\hline Albumin, g/dL & $3.2(2.7-3.5)$ & $3.5(3.1-3.9)$ & .003 \\
\hline $\mathrm{B} / \mathrm{A}$ ratio, $\mathrm{mg} / \mathrm{g}$ & $11.42(8.1-17.3)$ & $5.57(4.08-7.9)$ & $<.001$ \\
\hline \multicolumn{4}{|c|}{$\begin{array}{l}\text { Data are expressed as } n(\%) \text { or median }(25 \text { th to } 75 \text { th percentile range). } \\
\text { * Comparison with semi-quantitative procalcitonin levels of }<0.5 \mathrm{ng} / \mathrm{mL} \text {. } \\
\text { IC }=\text { intensive care } \\
\text { CURB- } 65=\text { confusion, urea nitrogen, breathing frequency, blood pressure, } \geq 65 \text { years of age } \\
\text { A-DROP }=\text { age, dehydration, respiratory failure, orientation disturbance, pressure } \\
\text { B/A ratio = blood urea nitrogen to serum albumin ratio }\end{array}$} \\
\hline
\end{tabular}

a semi-quantitative serum procalcitonin level of $\geq 10.0$ $\mathrm{ng} / \mathrm{mL}$ on hospital admission indicated a high probability for requiring intensive care; (3) elevation of the semiquantitative serum procalcitonin level was more frequently observed in subjects with a proven pathogen, particularly pneumococcal pneumonia; and (4) the B/A ratio on hospital admission was as accurate as CURB-65 and A-DROP scores for predicting mortality and the need for intensive care.

Procalcitonin is well known as a systemic inflammatory protein induced upon bacterial infection and as a diagnostic biomarker for estimating the likelihood of septic infection. The serum procalcitonin level shows a strong positive correlation with the severity of sepsis..$^{16,17}$ Septic shock, the most severe form of sepsis, is defined as sepsis-induced hypotension that persists despite adequate fluid re- suscitation and requires treatment with vasopressor agents. ${ }^{18}$ Many patients with septic shock have been reported to have serum procalcitonin levels $\geq 10.0 \mathrm{ng} /$ $\mathrm{mL} .{ }^{16,17}$ Moreover, many critically ill patients progressing to ARDS had serum procalcitonin levels $\geq 10.0 \mathrm{ng} / \mathrm{mL} .{ }^{19}$ Similarly, the present study revealed that subjects with semi-quantitative serum procalcitonin levels $\geq 10.0 \mathrm{ng} / \mathrm{mL}$ required intensive care, including vasopressor administration or mechanical ventilation, more frequently than those with levels of $<10.0 \mathrm{ng} / \mathrm{mL}$. However, over one half of the subjects who required intensive care had semi-quantitative serum procalcitonin levels of $<10.0 \mathrm{ng} / \mathrm{mL}$. In particular, $21.9 \%$ of them had a negative value $(<0.5$ $\mathrm{ng} / \mathrm{mL}$ ). A former CAP study showed that although a positive correlation was observed between the probability of ICU admission and serum procalcitonin levels, about one 
half of the patients who were admitted to ICUs had serum procalcitonin levels of $<0.5 \mathrm{ng} / \mathrm{mL} .{ }^{20}$ In short, semiquantitative serum procalcitonin levels $\geq 10.0 \mathrm{ng} / \mathrm{mL}$ might indicate a high probability of need for intensive care, but the lower levels of semi-quantitative serum procalcitonin cannot exclude the possibility of the need for intensive care.

The quantitative serum procalcitonin level at the time of hospital admission has been shown to be a reliable prognostic indicator in patients with CAP. $6,8,21$ However, in the present study, we did not find the semi-quantitative serum procalcitonin test to be useful for predicting mortality from CAP. We propose 2 explanations for this discrepancy. First, the semi-quantitative serum procalcitonin test may be inaccurate. One study ${ }^{22}$ performed in a pediatric emergency department found that 103 of 359 pairs of PCT-Q and quantitative procalcitonin measurements were discordant. Another study ${ }^{23}$ found that PCT-Q was frequently one grade higher or lower than would be indicated by the quantitative measurement. Second, the grades defined by the semi-quantitative serum procalcitonin test may be too coarse to be useful in patients with CAP. Elevation of the serum procalcitonin level in patients with CAP, unless sepsis is present, is generally minimal. ${ }^{24}$ Schuetz et $\mathrm{al}^{20}$ showed that although the serum procalcitonin level was significantly higher in non-survivors of CAP than in survivors, the difference between the median values was very small $(0.39 \mathrm{ng} / \mathrm{mL})$. In contrast, PCT-Q categorizes serum procalcitonin levels into only 4 grades $(<0.5,0.5$ to $<2.0$, 2.0 to $<10.0$, and $\geq 10.0 \mathrm{ng} / \mathrm{mL}$ ). These wide ranges may be inadequate for predicting mortality due to CAP.

In contrast to the results of the present study, Kasamatsu et $\mathrm{al}^{9}$ showed that the semi-quantitative procalcitonin measurement was useful for predicting mortality from CAP. We can propose 2 possible explanations for this discrepancy. First, the timing of blood sampling differed between the two studies. We included only subjects whose semiquantitative procalcitonin measurements had been performed on hospital admission, whereas the prior study included subjects whose measurements had been performed within $24 \mathrm{~h}$ of hospital admission. The change in serum procalcitonin level is drastic in subjects with systemic bacterial infection. A study 25 using healthy volunteers demonstrated that the concentration of serum procalcitonin peaked at $6 \mathrm{~h}$ after the injection of endotoxin. In contrast, a decline in serum procalcitonin level was observed within $24 \mathrm{~h}$ of the start of appropriate treatment. ${ }^{26}$ Earlier studies $^{27,28}$ in sepsis patients showed that serum procalcitonin levels at $24 \mathrm{~h}$ after hospital admission predicted mortality more accurately than those measured on hospital admission. In short, the procalcitonin levels measured at $24 \mathrm{~h}$ after hospital admission may have already reflected the patients' clinical course. Second, the study population differed between the two studies. For example, to evaluate the prognostic value of commonly used laboratory biomarkers, we excluded subjects who had advanced liver diseases or chronic kidney diseases. The serum procalcitonin level tends to be higher in patients with cirrhosis or renal impairment. ${ }^{29,30}$ These comorbidities may have affected the results in both studies.

The Pneumonia Severity Index is based on patient characteristics, comorbid illnesses, physical examination results, radiographic findings, and laboratory findings. ${ }^{1}$ Consistent with the present study, the Pneumonia Severity Index has been shown to perform as a reliable predictor of mortality from and severity of CAP, but it may be complex to calculate and difficult to implement in routine clinical practice. ${ }^{31}$ Therefore, other simple indicators that perform as well as the Pneumonia Severity Index should be considered in CAP. CURB-65 and A-DROP scales are simple and widely used severity scoring systems for CAP. ${ }^{2,3}$ In the present study, these simple severity scores were capable of predicting mortality and severity of disease in subjects with CAP. However, these severity scoring systems have some weaknesses. First, it is difficult for clinicians to evaluate changes in mental status due to pneumonia in elderly patients. ${ }^{5}$ Second, these scoring systems can underestimate the potential severity of CAP in young patients. ${ }^{32}$

Of the many possible laboratory biomarkers, several serum markers, such as D-dimer, ${ }^{33}$ cortisol, ${ }^{34} \mathrm{~B}$-type natriuretic peptide, ${ }^{35}$ mid-regional pro-atrial natriuretic peptide, ${ }^{36}$ and copeptin ${ }^{37}$ levels, correlate well with the clinical outcomes of patients with CAP. However, these parameters are unsuitable for routine use in patients with CAP due to the cost of the assays or the retrospective nature of the results. In contrast, the blood urea nitrogen and serum albumin levels are commonly tested, can be measured quickly, and have been reported as prognostic indicators of CAP. ${ }^{2,10-13}$ We have previously shown that the combination of blood urea nitrogen and serum albumin was more accurate for predicting mortality from and severity of disease in patients with CAP than each individually. ${ }^{14}$ Blood urea nitrogen levels are frequently elevated in patients with dehydration, whereas low serum albumin levels occur in those with malnutrition and inflammation. ${ }^{38,39}$ Therefore, a high B/A ratio is associated with critical illness. In the present study, we have shown that the B/A ratio is a good indicator of both the risk for mortality from and severity of CAP, with predictive values comparable to those of CURB-65 and A-DROP scores. The sensitivity, specificity, and positive and negative predictive values of the B/A ratio for mortality and the need for intensive care are presented in Supplemental Table 1 (see the supplementary materials at http://www.rcjournal. com). The optimal cutoff value of the B/A ratio for predicting mortality was $14.65 \mathrm{mg} / \mathrm{g}$, with $50.0 \%$ sensitivity, $96.4 \%$ specificity, a positive predictive value of $58.8 \%$, 


\section{Semi-Quantitative Procalcitonin in Community-Acquired Pneumonia}

and a negative predictive value of $94.9 \%$. Similarly, the optimal cutoff value of the $\mathrm{B} / \mathrm{A}$ ratio for predicting the need for intensive care was $9.85 \mathrm{mg} / \mathrm{g}$, with $59.4 \%$ sensitivity, $89.0 \%$ specificity, a positive predictive value of $48.7 \%$, and a negative predictive value of $92.5 \%$.

We must note several limitations of our present study. First, this study cohort included a limited number of subjects because it was a single-center study. To prove the usefulness of the semi-quantitative serum procalcitonin test and $\mathrm{B} / \mathrm{A}$ ratio on hospital admission for predicting the clinical outcomes of patients with CAP, additional studies involving a large number of subjects are needed. Second, we excluded $\sim 40 \%$ of admitted patients from this analysis due to the absence of semi-quantitative procalcitonin measurement on hospital admission. No significant differences were observed between the excluded patients and included subjects in age, gender, mortality, and the need for intensive care. However, we could not deny that such a high rate of exclusion might influence the results of our present study. Third, most subjects in our study cohort were of advanced age. Therefore, our mortality rate may be higher compared with that in earlier CAP studies. To evaluate the clinical importance of the semi-quantitative serum procalcitonin test and $\mathrm{B} / \mathrm{A}$ ratio on hospital admission in patients with CAP, additional studies including younger patients are needed.

In conclusion, the semi-quantitative serum procalcitonin level on hospital admission had little predictive value for mortality in patients with CAP. However, patients with serum procalcitonin levels $\geq 10.0 \mathrm{ng} / \mathrm{mL}$ had a high probability of requiring intensive care. In addition, the B/A ratio on hospital admission was a reliable predictor of the risk for mortality from and severity of CAP.

\section{REFERENCES}

1. Fine MJ, Auble TE, Yealy DM, Hanusa BH, Weissfeld LA, Singer $\mathrm{DE}$, et al. A prediction rule to identify low-risk patients with community-acquired pneumonia. N Engl J Med 1997;336(4):243-250.

2. Lim WS, van der Eerden MM, Laing R, Boersma WG, Karalus N, Town GI, et al. Defining community acquired pneumonia severity on presentation to hospital: an international derivation and validation study. Thorax 2003;58(5):377-382.

3. Yanagihara K, Kohno S, Matsusima T. Japanese guidelines for the management of community-acquired pneumonia. Int J Antimicrob Agents 2001;18(Suppl 1):S45-S48.

4. Rudolph JL, Zanin NM, Jones RN, Marcantonio ER, Fong TG, Yang FM, et al. Hospitalization in community-dwelling persons with Alzheimer's disease: frequency and causes. J Am Geriatr Soc 2010; 58(8):1542-1548.

5. Shah BA, Ahmed W, Dhobi GN, Shah NN, Khursheed SQ, Haq I. Validity of pneumonia severity index and CURB-65 severity scoring systems in community acquired pneumonia in an Indian setting. Indian J Chest Dis Allied Sci 2010;52(1):9-17.

6. Masiá M, Gutiérrez F, Shum C, Padilla S, Navarro JC, Flores E, Hernández I. Usefulness of procalcitonin levels in community-acquired pneumonia according to the patients outcome research team pneumonia severity index. Chest 2005;128(4):2223-2229.
7. Horie M, Ugajin M, Suzuki M, Noguchi S, Tanaka W, Yoshihara H, et al. Diagnostic and prognostic value of procalcitonin in community-acquired pneumonia. Am J Med Sci 2012;343(1):30-35.

8. Park JH, Wee JH, Choi SP, Oh SH. The value of procalcitonin level in community-acquired pneumonia in the ED. Am J Emerg Med 2012;30(7):1248-1254.

9. Kasamatsu Y, Yamaguchi T, Kawaguchi T, Tanaka N, Oka H, Nakamura $\mathrm{T}$, et al. Usefulness of a semi-quantitative procalcitonin test and the A-DROP Japanese prognostic scale for predicting mortality among adults hospitalized with community-acquired pneumonia. Respirology 2012;17(2):330-336.

10. Farr BM, Sloman AJ, Fisch MJ. Predicting death in patients hospitalized for community-acquired pneumonia. Ann Intern Med 1991; 115(6):428-436.

11. Raz R, Dyachenko P, Levy Y, Flatau E, Reichman N. A predictive model for the management of community-acquired pneumonia. Infection 2003;31(1):3-8.

12. Potgieter PD, Hammond JM. The intensive care management, mortality and prognostic indicators in severe community-acquired pneumococcal pneumonia. Intensive Care Med 1996;22(12):1301-1306.

13. Lee JH, Kim J, Kim K, Jo YH, Rhee J, Kim TY, et al. Albumin and $\mathrm{C}$-reactive protein have prognostic significance in patients with community-acquired pneumonia. J Crit Care 2011;26(3):287-294.

14. Ugajin M, Yamaki K, Iwamura N, Yagi T, Asano T. Blood urea nitrogen to serum albumin ratio independently predicts mortality and severity of community-acquired pneumonia. Int J Gen Med 2012;5: 583-589.

15. Bossuyt PM, Reitsma JB, Bruns DE, Gatsonis CA, Glasziou PP, Irwig LM, et al. Towards complete and accurate reporting of studies of diagnostic accuracy: the STARD initiative. Ann Intern Med 2003; 138(1):40-44

16. Brunkhorst FM, Wegscheider K, Forycki ZF, Brunkhorst R. Procalcitonin for early diagnosis and differentiation of SIRS, sepsis, severe sepsis, and septic shock. Intensive Care Med 2000;26(Suppl 2):S148S152.

17. Harbarth S, Holeckova K, Froidevaux C, Pittet D, Ricou B, Grau GE, et al. Diagnostic value of procalcitonin, interleukin-6, and interleukin- 8 in critically ill patients admitted with suspected sepsis. Am J Respir Crit Care Med 2001;164(3):396-402.

18. Bone RC, Balk RA, Cerra FB, Dellinger RP, Fein AM, Knaus WA, et al. Definitions for sepsis and organ failure and guidelines for the use of innovative therapies in sepsis. The ACCP/SCCM Consensus Conference Committee. American College of Chest Physicians/Society of Critical Care Medicine. Chest 1992;101(6):1644-1655.

19. Giamarellos-Bourboulis EJ, Mega A, Grecka P, Scarpa N, Koratzanis G, Thomopoulos G, Giamarellou H. Procalcitonin: a marker to clearly differentiate systemic inflammatory response syndrome and sepsis in the critically ill patient? Intensive Care Med 2002;28(9): 1351-1356.

20. Schuetz P, Suter-Widmer I, Chaudri A, Christ-Crain M, Zimmerli W, Mueller B. Prognostic value of procalcitonin in community-acquired pneumonia. Eur Respir J 2011;37(2):384-392.

21. Krüger S, Ewig S, Marre R, Papassotiriou J, Richter K, von Baum H, et al. Procalcitonin predicts patients at low risk of death from community-acquired pneumonia across all CRB-65 classes. Eur Respir J 2008;31(2):349-355.

22. Manzano S, Bailey B, Girodias JB, Cousineau J, Delvin E, Gervaix A. Comparison of procalcitonin measurement by a semi-quantitative method and an ultra-sensitive quantitative method in a pediatric emergency department. Clin Biochem 2009;42(15):1557-1560.

23. Kordek A, Podraza W, Czajka R. Reliability of semiquantitative determination of procalcitonin serum concentrations in neonates. Diagn Microbiol Infect Dis 2006;56(1):31-34. 


\section{Semi-Quantitative Procalcitonin in Community-Acquired Pneumonia}

24. Polzin A, Pletz M, Erbes R, Raffenberg M, Mauch H, Wagner S, et al. Procalcitonin as a diagnostic tool in lower respiratory tract infections and tuberculosis. Eur Respir J 2003;21(6):939-943.

25. Dandona P, Nix D, Wilson MF, Aljada A, Love J, Assicot M, Bohuon C. Procalcitonin increase after endotoxin injection in normal subjects. J Clin Endocrinol Metab 1994;79(6):1605-1608.

26. Viallon A, Guyomarc'h P, Guyomarc'h S, Tardy B, Robert F, Marjollet $\mathrm{O}$, et al. Decrease in serum procalcitonin levels over time during treatment of acute bacterial meningitis. Crit Care 2005;9(4): R344-350.

27. Pettilä V, Hynninen M, Takkunen O, Kuusela P, Valtonen M. Predictive value of procalcitonin and interleukin 6 in critically ill patients with suspected sepsis. Intensive Care Med 2002;28(9):12201225.

28. Phua J, Koay ES, Lee KH. Lactate, procalcitonin, and amino-terminal pro-B-type natriuretic peptide versus cytokine measurements and clinical severity scores for prognostication in septic shock. Shock 2008;29(3):328-333.

29. Rahimkhani M, Einollahi N, Khavari Daneshvar H, Dashti N. Survey of serum procalcitonin in cirrhotic patients. Acta Med Iran 2013; 51(3):153-156.

30. Amour J, Birenbaum A, Langeron O, Le Manach Y, Bertrand M, Coriat $\mathrm{P}$, et al. Influence of renal dysfunction on the accuracy of procalcitonin for the diagnosis of postoperative infection after vascular surgery. Crit Care Med 2008;36(4):1147-1154.

31. Singanayagam A, Chalmers JD, Hill AT. Severity assessment in community acquired pneumonia: a review. QJM 2009;102(6):379388.

32. Chalmers JD, Singanayagam A, Hill AT. Predicting the need for mechanical ventilation and/or inotropic support for young adults admitted to the hospital with community-acquired pneumonia. Clin Infect Dis 2008;47(12):1571-1574.

33. Querol-Ribelles JM, Tenias JM, Grau E, Querol-Borras JM, Climent JL, Gomez E, Martinez I. Plasma D-dimer levels correlate with outcomes in patients with community-acquired pneumonia. Chest 2004;126(4): 1087-1092.

34. Christ-Crain M, Stolz D, Jutla S, Couppis O, Müller C, Bingisser R, et al. Free and total cortisol levels as predictors of severity and outcome in community-acquired pneumonia. Am J Respir Crit Care Med 2007;176(9):913-920.

35. Christ-Crain M, Breidthardt T, Stolz D, Zobrist K, Bingisser R, Miedinger D, et al. Use of B-type natriuretic peptide in the risk stratification of community-acquired pneumonia. J Intern Med 2008; 264(2):166-176.

36. Masiá M, Papassotiriou J, Morgenthaler NG, Hernández I, Shum C, Gutiérrez F. Midregional pro-A-type natriuretic peptide and carboxy-terminal provasopressin may predict prognosis in communityacquired pneumonia. Clin Chem 2007;53(12):2193-2201.

37. Krüger S, Ewig S, Giersdorf S, Hartmann O, Suttorp N, Welte T. Cardiovascular and inflammatory biomarkers to predict short- and long-term survival in community-acquired pneumonia: results from the German Competence Network, CAPNETZ. Am J Respir Crit Care Med 2010;182(11):1426-1434.

38. Hedlund JU, Hansson LO, Ortqvist AB. Hypoalbuminemia in hospitalized patients with community-acquired pneumonia. Arch Intern Med 1995;155(13):1438-1442.

39. Al-Shaiba R, McMillan DC, Angerson WJ, Leen E, McArdle CS, Horgan P. The relationship between hypoalbuminaemia, tumour volume and the systemic inflammatory response in patients with colorectal liver metastases. Br J Cancer 2004;91(2):205-207. 